\title{
Development and validation of spectrophotometric methods for determination of ceftazidime in pharmaceutical dosage forms
}

\author{
BASAVARAJ HIREMATH \\ BENNIKALLU HIRE MATHADA \\ MRUTHYUNJAYASWAMY* \\ Department of Chemistry, Gulbarga \\ University, Gulbarga-585106, India
}

Accepted June 30, 2008
Two spectrophotometric methods for the determination of ceftazidime (CFZM) in either pure form or in its pharmaceutical formulations are described. The first method is based on the reaction of 3-methylbenzothiazolin-2-one hydrazone (MBTH) with ceftazidime in the presence of ferric chloride in acidic medium. The resulting blue complex absorbs at $\lambda_{\max } 628 \mathrm{~nm}$. The second method describes the reaction between the diazotized drug and $N$-(1-naphthyl)ethylenediamine dihydrochloride (NEDA) to yield a purple colored product with $\lambda_{\max }$ at $567 \mathrm{~nm}$. The reaction conditions were optimized to obtain maximum color intensity. The absorbance was found to increase linearly with increasing the concentration of CFZM; the systems obeyed the Beer's law in the range 2-10 and 10-50 $\mu \mathrm{g} \mathrm{mL}{ }^{-1}$ for MBTH and NEDA methods, resp. LOD, LOQ and correlation coefficient values were $0.15,0.79$ and $0.50,2.61$. No interference was observed from common excipients present in pharmaceutical formulations. The proposed methods are simple, sensitive, accurate and suitable for quality control applications.

Keywords: ceftazidime, diazotization, spectrophotometry, pharmaceutical formulation

Ceftazidime is (Z)-(7R)-7-[2-(2-aminothiazol-4-yl)-2-(1-carboxy-1-methoxyimino)acetamido]-3-(1-pyridiniomethyl)-3-cephem-4-carboxylate pentahydrate (CFZM) $(1,2)$. It is a third generation cephalosporin antibiotic characterized by a broad antibacterial spectrum and resistant to beta-lactamase producing organisms in addition to its antimicrobial activity against Streptococci, Staphylococci, Pneumococci, etc. Several analytical procedures are available in the literature for the analysis of ceftazidime, via high performance liquid chromatography (4-7), charge transfer complexation (8), and spectrophotometric methods (9-14). Most of the spectrophotometric methods reported earlier suffer from disadvantages like a narrow linearity range, requiring heating or extraction, long time for the reaction to complete, use of non-aqueous systems, low stability of the colored prod-

\footnotetext{
* Correspondence, e-mail: bhmmswamy66@rediffmail.com
} 
B. Hiremath and B. H. M. Mruthyunjayaswamy: Development and validation of spectrophotometric methods for determination of ceftazidime in pharmaceutical dosage forms, Acta Pharm. 58 (2008) 275-285.

uct formed. In continuation of our research on spectrophotometric determination of organic compounds of pharmaceutical importance $(15,16)$, the present communication reports two spectrophotometric methods for the determination of ceftazidime in either pure form or in pharmaceutical preparations. Both regents are used for the first time in ceftazidime analysis.

\section{EXPERIMENTAL}

\section{Apparatus}

An ELICO Model SL-164 double beam, UV-VIS spectrophotometer (Elico India Ltd., India) with $1.0 \mathrm{~cm}$ matched quartz cells was used for absorbance measurements.

\section{Reagents and materials}

Ceftazidime (gift sample from Alkem Laboratories Ltd., India), 3-methylbenzothiazolin-2-one hydrazone (MBTH) (Himedia Laboratories Pvt. Ltd., India, certified to be 99.0\%) and N-(1-naphthyl)ethylenediamine dihydrochloride (NEDA) (S. d. Fine Chem., India, certified to be $98.5 \%$ ) were used. All other chemicals and solvents used were of analytical reagent grade.

The following dosage forms containing ceftazidime were purchased from local commercial sources: 1 - Tazid injections equivalent to $250 \mathrm{mg}$ ceftazidime (Alkem Laboratories Ltd., India), 2 - Tizime injections equivalent to $500 \mathrm{mg}$ (Lupin Laboratories Ltd.) and 3 - Cefazid injections equivalent to $1000 \mathrm{mg}$ (Biochem Pharmaceutical Inds., India).

\section{Standard solutions}

A stock solution of ceftazidime $\left(1 \mathrm{mg} \mathrm{mL}^{-1}\right)$ in water was kept in dark to avoid drug degradation. The working standard solution of ceftazidime containing $100 \mu \mathrm{g} \mathrm{mL}^{-1}$ was prepared by dilution.

Aqueous solutions $(0.2 \%)$ of MBTH $\left(8.6 \times 10^{-3} \mathrm{~mol} \mathrm{~L}^{-1}\right)$ and NEDA $\left(8 \times 10^{-3} \mathrm{~mol} \mathrm{~L}^{-1}\right)$ were freshly prepared.

\section{Analytical procedures}

Method I (MBTH method). - Aliquots of the working standard solution of the drug $(0.2-1.0 \mathrm{~mL})\left(100 \mu \mathrm{g} \mathrm{mL}^{-1}\right)$ were transferred into $10-\mathrm{mL}$ calibrated flasks. To each aqueous solution of $\mathrm{FeCl}_{3}\left(1.5 \mathrm{~mL}, 3 \times 10^{-2} \mathrm{~mol} \mathrm{~L}^{-1}\right)$, an aqueous solution of MBTH $(1.0 \mathrm{~mL}$, $8.6 \times 10^{-3} \mathrm{~mol} \mathrm{~L}^{-1}$ ) was added. The solutions were swirled and allowed to stand for 5 min. Then hydrochloric acid $\left(1.0 \mathrm{~mL}, 1 \times 10^{-2} \mathrm{~mol} \mathrm{~L}^{-1}\right)$ was added and made up to the mark with water. The absorbance was measured at $628 \mathrm{~nm}$ against the corresponding reagent blank and calibration graph was constructed.

Method II (NEDA method). - Aliquots of the working standard solution of the drug (1.0-5.0 mL) $\left(100 \mu \mathrm{g} \mathrm{mL}^{-1}\right)$ were transferred into $10-\mathrm{mL}$ calibrated flasks. Hydrochloric acid $\left(0.2 \mathrm{~mL}, 11.3 \mathrm{~mol} \mathrm{~L}^{-1}\right)$ was added, cooled in an ice bath and aqueous solution of 
B. Hiremath and B. H. M. Mruthyunjayaswamy: Development and validation of spectrophotometric methods for determination of ceftazidime in pharmaceutical dosage forms, Acta Pharm. 58 (2008) 275-285.

$\mathrm{NaNO}_{2}(1.0 \mathrm{~mL}, 0.145 \mathrm{~mol} \mathrm{~L}-1)$ was added. The solutions were cooled to $0{ }^{\circ} \mathrm{C}$ and an aqueous solution of ammonium sulfamate $\left(0.5 \mathrm{~mL}, 8.8 \times 10^{-2} \mathrm{~mol} \mathrm{~L}^{-1}\right)$ was added and stirred for $5 \mathrm{~min}$. Then the aqueous solution of NEDA $\left(1.0 \mathrm{~mL}, 8 \times 10^{-3} \mathrm{~mol} \mathrm{~L}^{-1}\right)$ was added and made up to the mark with water. The solutions were mixed thoroughly and the absorbance was measured at $567 \mathrm{~nm}$ against reagent blank and a calibration graph was constructed.

\section{Validation}

The linearity, slope and the intercepts were calculated using the regression equation. Precision and accuracy of the proposed methods were tested by carrying out the determination of eight replicates of pure and commercial samples of the drug, whose concentration was within Beer's law range. Values of the standard deviation (SD), relative standard deviation (RSD) and range of error at 95\% confidence level were calculated (17). The two methods have been applied to various pharmaceutical formulations and recovery studies have been made by the standard-addition method.

Intra-day precision and intra-day error of the methods were assessed from the results of eight replicate analyses on the pure drug solution. The mean values and relative standard deviation values for replicate analysis at three different concentration levels were calculated.

Accuracy of the methods was determined by recovery studies via the standard-addition method.

The limit of detection $(L O D)$ and limit of quantification $(L O Q)$ were calculated according to the current ICH guidelines (18) as the ratio of 3.3 and 10 standard deviation of the blank $(n=7)$, respectively, and the slope of the calibration line.

Selectivity studies. - To check the interference $10 \mu \mathrm{g} \mathrm{mL}^{-1}$ CFZM was selected for the MBTH method; for the NEDA method, $20 \mu \mathrm{g} \mathrm{mL}-1$ CFZM was used. Before adding the reagents, a known amount of the interfering substance was added and the reaction was carried out for both methods. The extent of interference by various excipients that often accompany pharmaceutical formulations are tabulated in Table I.

\section{Assay of the drug in injection dosage forms}

The content of ten to twenty vials (depending on the content per vial) were mixed thoroughly. An amount of the powder equivalent to $100 \mathrm{mg}$ of active component was weighed into a 100-mL volumetric flask, about $60 \mathrm{~mL}$ of water was added and shaken thoroughly for about $20 \mathrm{~min}$. The volume was made up to the mark with water, shaken and filtered using filter paper. The filtrate was diluted sequentially to get $100 \mu \mathrm{g} \mathrm{mL}^{-1}$ of the drug.

\section{RESULTS AND DISCUSSION}

The methods are based on $(i)$ the oxidative coupling reaction of the drug with 3-methylbenzothiazolin-2-one hydrazone (MBTH) in the presence of ferric chloride in acidic 
B. Hiremath and B. H. M. Mruthyunjayaswamy: Development and validation of spectrophotometric methods for determination of ceftazidime in pharmaceutical dosage forms, Acta Pharm. 58 (2008) 275-285.

Table I. Determination of ceftazidime in the presence of excipients and other substances

\begin{tabular}{lcc}
\hline \multirow{2}{*}{ Substance $^{\mathrm{a}}$} & \multicolumn{2}{c}{ Recovery $(\%)^{\mathrm{b}}$} \\
\cline { 2 - 3 } & MBTH $^{\mathrm{c}}$ & NEDA $^{\mathrm{d}}$ \\
\hline Magnesium stearate & $99.8 \pm 0.4$ & $99.4 \pm 0.2$ \\
Lactose & $99.5 \pm 0.2$ & $99.8 \pm 0.7$ \\
Dextrose & $99.9 \pm 0.5$ & $99.7 \pm 0.1$ \\
Starch & $99.9 \pm 0.5$ & $99.5 \pm 0.3$ \\
Gum acacia & $99.8 \pm 0.3$ & $100.0 \pm 0.1$ \\
Talc & $99.6 \pm 0.4$ & $99.8 \pm 0.3$ \\
Carboxy methyl cellulose & $99.6 \pm 0.4$ & $99.7 \pm 0.1$ \\
Sodium alginate & $99.7 \pm 0.3$ & $99.9 \pm 0.3$ \\
\hline
\end{tabular}

\footnotetext{
a Amount: $40 \mathrm{mg}$.

b Mean $\pm S D, n=5$.

${ }^{c}$ Concentration ratio drug to excipient 1:400.

d Concentration ratio drug to excipient 1:200.
}

medium, and (ii) the coupling reaction between the diazotized drug and $N$-(1-naphthyl)ethylenediamine dihydrochloride (NEDA) in aqueous medium.

\section{Reaction products}

The absorbance spectra of the bluish colored product (CFZM-MBTH) with $\lambda_{\max }$ of $628 \mathrm{~nm}$ and that of the purple colored product (CFZM-NEDA) with $\lambda_{\max } 567 \mathrm{~nm}$ are shown in Fig. 1. The above mentioned blanks have practically negligible absorption in both systems.

Fig. 1. Absorbance spectra of (CFZM-MBTH) and (CFZM-NEDA) reaction products (initial concentration of CFZM was 10 and $20 \mu \mathrm{g} \mathrm{mL}^{-1}$, respectively).

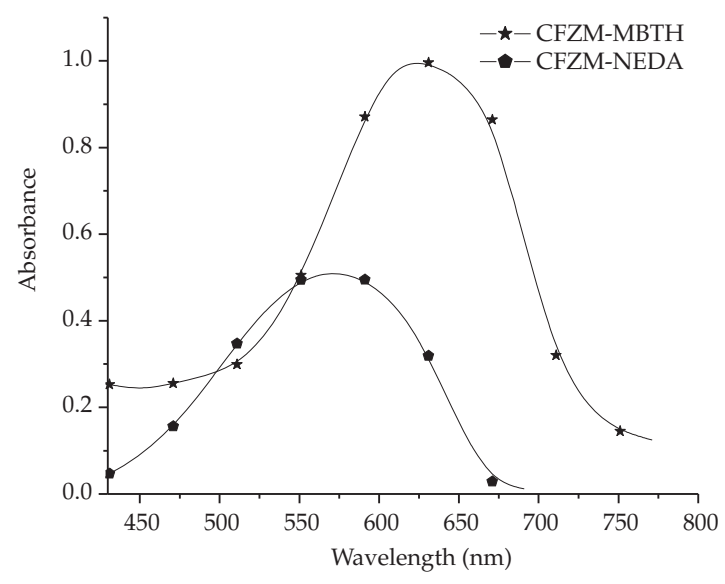


B. Hiremath and B. H. M. Mruthyunjayaswamy: Development and validation of spectrophotometric methods for determination of ceftazidime in pharmaceutical dosage forms, Acta Pharm. 58 (2008) 275-285.

In the MBTH method, the drug reacts with $\mathrm{MBTH}$ in the presence of $\mathrm{FeCl}_{3}$ in acidic medium to give a blue colored product. Actually, this is an iron catalyzed oxidative coupling reaction of MBTH with the drug. Under the reaction conditions, on oxidation, MBTH loses two electrons and one proton forming an electrophilic intermediate, which is the active coupling species. This intermediate undergoes electrophilic substitution with the drug to form the colored product. The NEDA method includes diazotization of the drug to form diazonium salt, which on coupling with NEDA yields a purple azo dye. The reaction mechanisms (CFZM-MBTH) and (CFZM-NEDA) for both methods are shown in Schemes 1 and 2, respectively.

The colored products were found to be stable for 18 and 6 hours, respectively, at room temperature. Reproducible results were obtained in the temperature range of $20-40{ }^{\circ} \mathrm{C}$. An increase in temperature above $40{ }^{\circ} \mathrm{C}$ decreased the absorbance readings in the NEDA method, indicating decomposition of the product.<smiles>Cn1/c(=N/N)sc2ccccc21</smiles>

MBTH

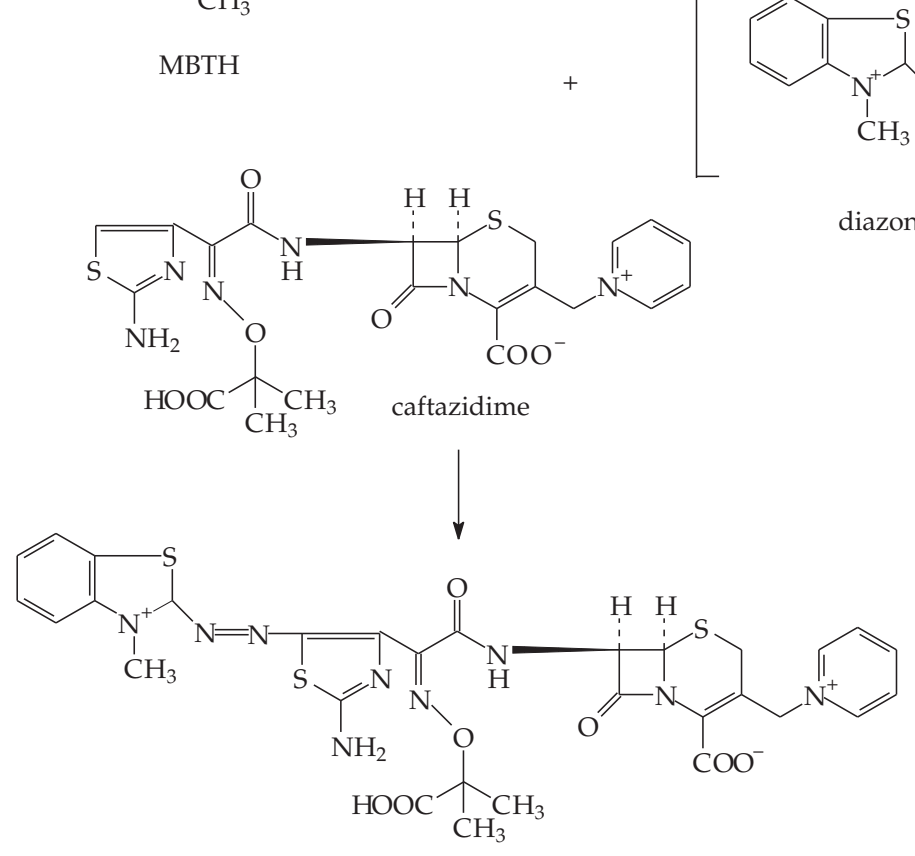

blue color

Scheme 1 


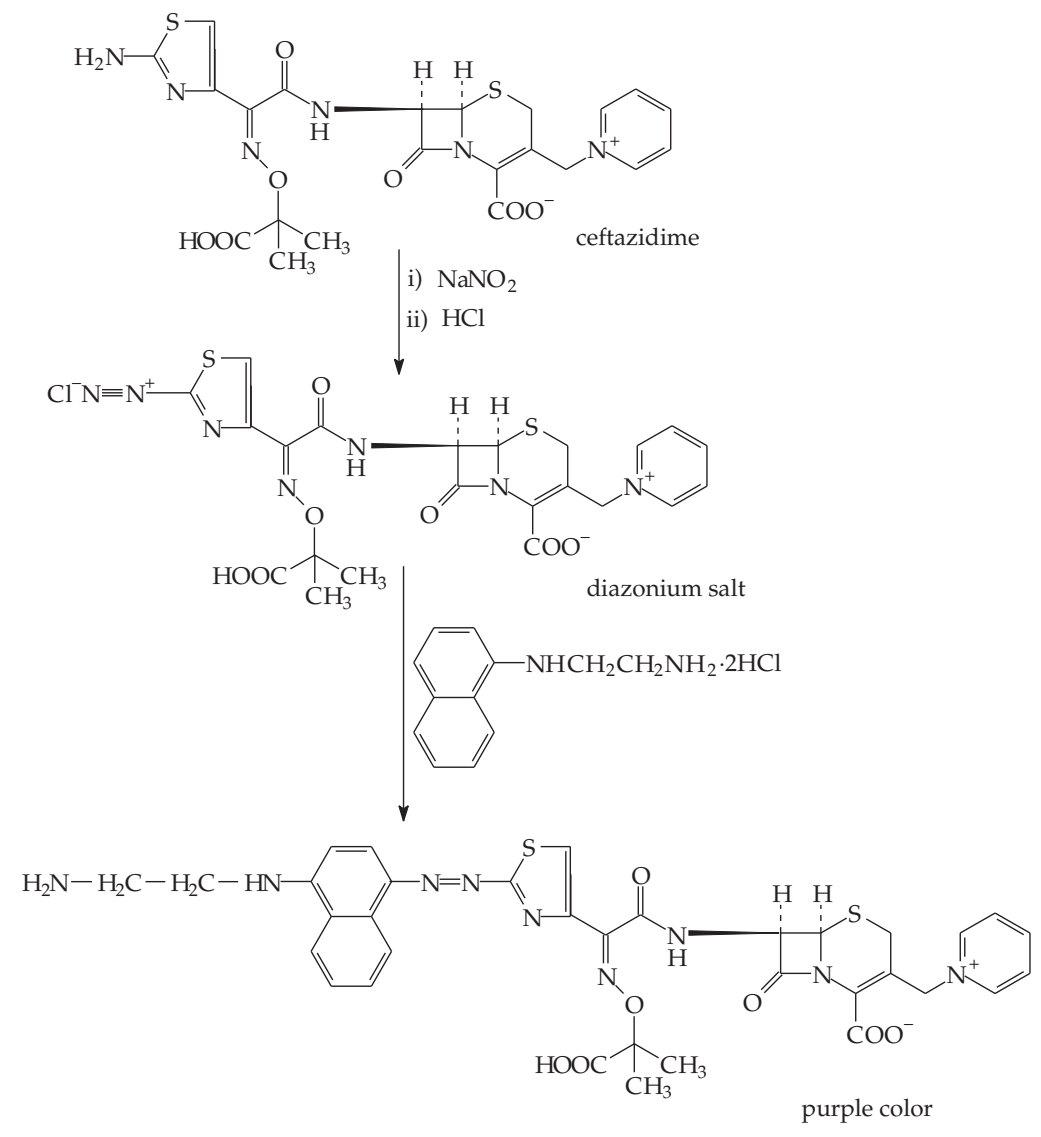

Scheme 2

\section{Optimization of reaction conditions}

For the MBTH method, to achieve maximum color intensity $8.6 \times 10^{-4} \mathrm{~mol} \mathrm{~L}^{-1}$ MBTH, $4.5 \times 10^{-3} \mathrm{~mol} \mathrm{~L}^{-1}$ ferric chloride and $1 \times 10^{-3} \mathrm{~mol} \mathrm{~L}^{-1}$ hydrochloric acid were necessary.

For NEDA method, for the development of maximum color intensity $0.226 \mathrm{~mol} \mathrm{~L}^{-1}$ hydrochloric acid, $1.45 \times 10^{-2} \mathrm{~mol} \mathrm{~L}^{-1}$ sodium nitrite, $\left(4.4 \times 10^{-3} \mathrm{~mol} \mathrm{~L}^{-1}\right)$ ammonium sulfamate and $\left.8 \times 10^{-4} \mathrm{~mol} \mathrm{~L}^{-1}\right)$ NEDA were necessary. The excess of nitrite could be removed by the addition of $\left(4.4 \times 10^{-3} \mathrm{~mol} \mathrm{~L}^{-1}\right)$ ammonium sulfamate solution. An excess of ammonium sulfamate has no effect on the color intensity of the product formed. In the case of NEDA as a coupling agent, dilution of the colored solution with different solvents like water, methanol, ethanol, acetic acid and acetonitrile was tested. However, dilution with water gave maximum intensity and stability of the color. Temperature of 30 ${ }^{\circ} \mathrm{C}$ is recommended for the absorbance measurements of colored products. 
B. Hiremath and B. H. M. Mruthyunjayaswamy: Development and validation of spectrophotometric methods for determination of ceftazidime in pharmaceutical dosage forms, Acta Pharm. 58 (2008) 275-285.

\section{Figures of merit}

Linear correlations were found between absorbance at $\lambda_{\max }$ and CFZM concentration and are described by the regression equations:

$$
\begin{gathered}
\mathrm{A}=0.078+0.138 \gamma ; R=0.9999, n=8 \text { (MBTH method) } \\
\mathrm{A}=0.0199+0.00534 \gamma, R=0.9989, n=8 \text { (NEDA method) }
\end{gathered}
$$

where $\mathrm{A}$ is the absorbance and $\gamma$ is the concentration in $\mu \mathrm{g} \mathrm{mL}-1, R$ is the correlation coefficient and $n$ is the number of measurement levels. Beer's law is obeyed for $2-10$ and 10-50 $\mu \mathrm{g} \mathrm{mL}^{-1}$ for the MBTH and NEDA methods, respectively. Calculated apparent molar absorptivity values were found to be $6.0 \times 10^{4}$ and $1.3 \times 10^{4} \mathrm{~L} \mathrm{~mol}^{-1} \mathrm{~cm}^{-1}$ for the MBTH method and NEDA methods, respectively.

The $L O D$ values were found to be 0.15 and $0.79 \mu \mathrm{g} \mathrm{mL}^{-1}$ for CFZM with MBTH and with NEDA, respectively. The $L O Q$ values were 0.50 and $2.61 \mu \mathrm{g} \mathrm{mL}-1$ for CFZM with MBTH and with NEDA, respectively. These values indicate that the MBTH method is more sensitive than the NEDA method.

Table II summarizes the intra-day precision and intra-day error data for the assay of CFZM in pure drug solution by the proposed methods. The intra-day RSD values ranged from $0.1-0.4 \%$, reflecting the usefulness of the method in routine use, and $e_{\mathrm{r}}$ data was $\leq 2.0 \%$.

The results of the selectivity study as shown in Table I confirm that the proposed methods are accurate and precise even in the presence of various excipients. Amines such as aniline, piperidine, morpholine, interfere in the NEDA method, because of the diazotization reaction. It was found that in both methods, excipients like magnesium stearate, lactose, dextrose, starch, gum acacia, talc, carboxymethyl cellulose and sodium alginate in the concentration excess (1:400 and 1:200) over the drug do not interfere in MBTH and NEDA methods, respectively. Recoveries of CFZM in selectivity testing were found to be

Table II. Intra-day precision and intra-day error of the methods

\begin{tabular}{cccccc}
\hline Method & $\begin{array}{c}\text { CFZM }\left(\mu \mathrm{g} \mathrm{mL} \mathrm{mL}^{-1}\right) \\
\text { taken }\end{array}$ & $\begin{array}{c}\text { CFZM }\left(\mu \mathrm{g} \mathrm{mL} \mathrm{mL}^{-1}\right) \\
\text { found }\end{array}$ & $e_{r}(\%)$ & RSD $(\%)$ & $C L\left(\mu \mathrm{mL}^{-1}\right)$ \\
\hline \multirow{3}{*}{ MBTH } & 0.5 & 0.49 & 0.8 & 0.4 & $0.49 \pm 0.00_{2}$ \\
& 1.50 & 1.49 & 0.13 & 0.2 & $1.49 \pm 0.00_{2}$ \\
& 2.50 & 2.49 & 0.1 & 0.2 & $2.49 \pm 0.00_{4}$ \\
NEDA & 3.0 & 2.99 & 0.15 & 0.1 & $2.99 \pm 0.00_{1}$ \\
& 3.50 & 3.49 & 0.11 & 0.10 & $3.49 \pm 0.00_{3}$ \\
& 4.00 & 3.99 & 0.25 & 0.1 & $3.99 \pm 0.00_{2}$ \\
\hline
\end{tabular}

$e_{\mathrm{r}}$ - relative error.

$C L$ - confidence limits at $95 \%$ confidence level for seven degrees of freedom. 
B. Hiremath and B. H. M. Mruthyunjayaswamy: Development and validation of spectrophotometric methods for determination of ceftazidime in pharmaceutical dosage forms, Acta Pharm. 58 (2008) 275-285.

$99.7 \pm 0.4$ and $99.7 \pm 0.3 \%$ for MBTH and NEDA methods, respectively, indicating selectivity of both methods. Even precisionwise, the proposed methods are satisfactorily, with low RSD values ranging from 0.1 to $0.7 \%$.

\section{Application to dosage forms}

The proposed methods were applied to the analysis of CFZM in vials and the results were statistically compared with those obtained by the official HPLC method (7) by calculating the Student's $t$ - and $F$-values. The evaluated $t$ - and $F$-values were less than the tabulated values at the $95 \%$ confidence level for seven degrees of freedom (18), as revealed by the results complied in Table III. This actually suggests that the proposed methods are accurate and precise as the official method (7).

In order to further ascertain the accuracy and reliability of the methods, recovery experiments were performed by the standard-addition method. Pre-analyzed formulation was spiked with pure CFZM at three different levels and the total was found by the proposed methods. The percent recovery of pure drug added was in the range of 99.3-102.3\% for MBTH and from 97.6-101.5\% for NEDA. RSD ranged from 0.3 to $0.9 \%$. The results of this study summarized in Table IV indicate that neither the accuracy nor the precision of the methods is affected by the coformulated substances.

The proposed methods are simple, rapid and reliable. In contrast to the charge transfer complex method (6) reported earlier, the proposed methods are more sensitive, with a range of $2-10 \mu \mathrm{g} \mathrm{mL}^{-1}\left(7.85 \times 10^{-7}-1.57 \times 10^{-6} \mathrm{~mol} \mathrm{~L}^{-1}\right)$, and can be applied to a single vial so that vial to vial variation, if desirable, can be followed. Performance characteristics of the existing spectrophotometric methods $(15,16)$ and the present methods are compared in Table V, from which it is obviously clear that the proposed methods are free from drastic experimental conditions such as heating or extraction unlike many reported procedures. Both methods are highly sensitive compared to all the existing spectrophotometric methods, as shown by the molar absorptivity values and, in fact, the method using MBTH is the most sensitive method ever reported for CFZM. The proposed methods use eco-friendly and inexpensive chemicals and seldom employ organic solvents.

Table III. Assay of drug in pharmaceutical formulations (injections)

\begin{tabular}{|c|c|c|c|c|c|c|c|c|}
\hline \multirow[b]{2}{*}{ Preparation } & \multirow{2}{*}{$\begin{array}{l}\text { Label claim } \\
\text { (mg per vial) }\end{array}$} & \multicolumn{3}{|c|}{ Percent found ${ }^{\mathrm{a}}$} & \multicolumn{2}{|c|}{ Student $t$-value $\mathrm{e}^{\mathrm{b}}$} & \multicolumn{2}{|c|}{$F$-value ${ }^{c}$} \\
\hline & & MBTH & NEDA & $\begin{array}{l}\text { Reference } \\
\text { method }(7)\end{array}$ & MBTH & NEDA & MBTH & NEDA \\
\hline 1 & 250 & $99.8 \pm 0.5$ & $99.9 \pm 0.4$ & $99.9 \pm 0.6$ & 0.03 & 0.15 & 1.87 & 2.74 \\
\hline 2 & 500 & $99.7 \pm 0.3$ & $99.9 \pm 0.3$ & $100.0 \pm 0.4$ & 1.70 & 0.24 & 1.41 & 1.98 \\
\hline 3 & 1000 & $99.8 \pm 0.4$ & $99.9 \pm 0.3$ & $99.8 \pm 0.6$ & 0.44 & 0.21 & 2.03 & 3.17 \\
\hline
\end{tabular}

\footnotetext{
a Mean $\pm \mathrm{SD}, n=8$.

b Tabulated value at $95 \%$ confidence level is 2.365 .

c Tabulated value at $95 \%$ confidence level is 3.79 .
} 
B. Hiremath and B. H. M. Mruthyunjayaswamy: Development and validation of spectrophotometric methods for determination of ceftazidime in pharmaceutical dosage forms, Acta Pharm. 58 (2008) 275-285.

Table IV. Recovery by the standard-addition method

\begin{tabular}{cccccrr}
\hline & \multicolumn{3}{c}{ MBTH } & \multicolumn{3}{c}{ NEDA } \\
\hline Formulation & $\begin{array}{c}\text { Amount of } \\
\text { drug in } \\
\text { formulation } \\
(\mathrm{mg})\end{array}$ & $\begin{array}{c}\text { Amount of } \\
\text { drug added } \\
(\mathrm{mg})\end{array}$ & $\begin{array}{c}\text { Recovery } \\
(\%)^{\mathrm{a}}\end{array}$ & $\begin{array}{c}\text { Amount of } \\
\text { drug in } \\
\text { formulation } \\
(\mathrm{mg})\end{array}$ & $\begin{array}{c}\text { Amount of } \\
\text { drug added } \\
(\mathrm{mg})\end{array}$ & $\begin{array}{c}\text { Recovery } \\
(\%)^{\mathrm{a}}\end{array}$ \\
\hline \multirow{3}{*}{1} & 3.96 & 6.0 & $102.3 \pm 0.3$ & 2.96 & 5.0 & $99.6 \pm 0.4$ \\
& 3.96 & 9.0 & $100.0 \pm 0.4$ & 2.96 & 10.0 & $100.3 \pm 0.6$ \\
& 3.96 & 12.0 & $101.0 \pm 0.4$ & 2.96 & 15.0 & $101.1 \pm 0.3$ \\
& 3.88 & 6.0 & $102.0 \pm 0.8$ & 3.07 & 5.0 & $99.4 \pm 0.4$ \\
& 3.88 & 9.0 & $100.3 \pm 0.6$ & 3.07 & 10.0 & $100.5 \pm 0.3$ \\
& 3.88 & 12.0 & $99.3 \pm 0.7$ & 3.07 & 15.0 & $101.5 \pm 0.6$ \\
& 3.90 & 6.0 & $100.3 \pm 0.4$ & 2.96 & 5.0 & $97.6 \pm 0.9$ \\
& 3.90 & 9.0 & $99.6 \pm 0.8$ & 2.96 & 10.0 & $99.7 \pm 0.3$ \\
& 3.90 & 12.0 & $100.2 \pm 0.3$ & 2.96 & 15.0 & $100.8 \pm 0.7$ \\
\hline
\end{tabular}

a Mean $\pm S D, n=3$.

Table V. Comparison of spectrophotometric methods for ceftazidime assay

\begin{tabular}{ccccc}
\hline Reagent(s) used & $\lambda_{\text {max }}(\mathrm{nm})$ & Beer's law limits & $\begin{array}{c}\text { Molar absorptivity } \\
\left(\mathrm{L} \mathrm{mol}^{-1} \mathrm{~cm}^{-1}\right)\end{array}$ & Reference \\
\hline Pd(II)/SLS & 330 & $3.0-60 \mathrm{mg} \mathrm{mL}^{-1}$ & - & 9 \\
$\mathrm{KMnO}_{4}$ & 430.5 & $0.0-30 \mathrm{mg} \mathrm{mL}^{-1}$ & - & 10 \\
$\mathrm{NBD}^{-C l}$ & 414 & $63.66-254.66 \mathrm{mg} \mathrm{mL}^{-1}$ & - & 12 \\
Ammonium molybdate & 716 & $2-70 \mathrm{mg} \mathrm{mL}^{-1}$ & $2.70 \times 10^{3}$ & 14 \\
MBTH & 628 & $2-10 \mu \mathrm{g} \mathrm{mL}^{-1}$ & $6.02 \times 10^{4}$ & This paper \\
NEDA & 567 & $10-50 \mu \mathrm{g} \mathrm{mL}^{-1}$ & $1.29 \times 10^{4}$ & This paper \\
\hline
\end{tabular}

SLS - sodium lauryl sulfate

NBD-Cl - 4-chloro-7-nitrobenzofurazan

MBTH - 3-methylbenzothiazolin-2-one hydrazone

NEDA - N-(1-naphthyl)ethylenediamine dihydrochloride

\section{CONCLUSIONS}

Ceftazidime has been assayed in dosage forms using visible spectrophotometry. Two methods can be used to monitor the content uniformity of injections and purity of ceftazidime raw material. The methods could be considered for the determination of CFZM in quality control laboratories. 
B. Hiremath and B. H. M. Mruthyunjayaswamy: Development and validation of spectrophotometric methods for determination of ceftazidime in pharmaceutical dosage forms, Acta Pharm. 58 (2008) 275-285.

Acknowledgements. - The authors are thankful to Chairman, Department of Chemistry, Gulbarga University, Gulbarga, for providing research facilities. The authors also thank Dr. K. Basavaiah, Reader Department of Chemistry, University of Mysore, for his valuable suggestions.

\section{REFERENCES}

1. Martindale - The Complete Drug Reference, 33 ${ }^{\text {rd }}$ ed., Pharmaceutical Press, London 2002, p. 174.

2. Merck Index, $13^{\text {th }}$ ed., Merck and Co. Inc., Whitehouse Station 2001, p. 160.

3. B. G. Katzung, Basic and Clinical Pharmacology, $2^{\text {nd }}$ ed., Appleton and Lange, New York 1987, pp. 522-525.

4. S. D. Hanes, V. L. Herring and G. C. Wood, Alternative method for determination of ceftazidime in plasma by high-performance liquid chromatography, J. Chromatogr. B Biomed. Sci. Appl. 719 (1998) 245-250; DOI: 10.1016/S0378-4347(98)00407-1.

5. T. H. Doadrio, A. K. Rumelin and U. F. Orenga, Ceftazidime determination in serum by high-pressure liquid chromatography, Arzneim. Forsch. 54 (2004) 320-322.

6. A. F. M. El-Walily, A. A. Gazy, S. F. Belal and E. F. Khamis, Quantitative determination of some thiazole cephalosplorins through complexation with palladium(II) chloride, J. Pharm. Biomed. Anal. 22 (2000) 385-392; DOI: 10.1016/S0731-7085(99)00281-2.

7. The United States Pharmacopoeia 25, National Formulary 20, USP Convention, Rockville 2002, pp. 354-356.

8. Indian Pharmacopoeia, Controller of Publications, Delhi 1996, pp. 149-150.

9. V. Rodenas, M. S. Garcia, C. Sanchez-Pedreno and M. I. Albero, Spectrophotometric methods for the determination of cephradine or ceftazidime in human urine using batch and flow-injection procedures, J. Pharm. Biomed. Anal. 15 (1997) 1687-1693; DOI: 10.1016/S0731-7085(96)01963-2.

10. K. R. Khadiga, I. L. Bebawy and L. I. Abdel-Fattah, Stability-indicating spectrophotometric and densitometric methods for determination of some cephalosporins, J. AOAC. Int. 81 (1998) 386-396.

11. R. C. Vamsi, B. H. Sarojini, A. R. Geetha, M. O. Shobana, R. D. Umarani, L. N. Kavitha, S. N. Meyyanathan and B. S. Suresh, Spectrophotometric method for the determination of ceftazidime sodium, East. Pharm. 43 (2000) 143-144.

12. E. H. Abdellatef, A. A. Shalaby, M. H. Elsaid and M. M. Ayad, Colorimetric and titrimetric methods for determination of some cephalosporins in their pure and dosage forms, Sci. Pharm. 68 (2000) 263-273.

13. E. S. Marwa, M. N. Elbolkiny and M. H. Khalil, Spectrophotometric determination of acyclovir, ceftazidime pentahydrate, famotidine and isoxsuprine hydrochloride by ternary complex formation with eosin and $\mathrm{Cu}(\mathrm{II})$, Chin. Pharm. J. 55 (2003) 481-490.

14. E. S. Marwa, A. Shalaby, M. N. Elbolkiny and M. H. Khalil, Spectrophotometric determination of cefepime hydrochloride, cefoperazone sodium, ceftazidime pentahydrate, cefuroxime sodium and etamsylate using ammonium molybdate, Sci. Pharm. 71 (2003) 211-228.

15. B. Hiremath and B. H. M. Mruthyunjayaswamy, Development and validation of spectrophotometric methods for the determination of cefetamet in pharmaceutical dosage forms, Chin. J. Chem. 25 (2007) 1827-1831; DOI: wiley.com/10.1002/cjoc.200790337.

16. B. Hiremath and B. H. M. Mruthyunjayaswamy, Development and validation of spectrophotometric methods for determination of ceftriaxone sodium in pharmaceutical dosage forms, J. Indian Council Chem. 23 (2006) 111-115. 
B. Hiremath and B. H. M. Mruthyunjayaswamy: Development and validation of spectrophotometric methods for determination of ceftazidime in pharmaceutical dosage forms, Acta Pharm. 58 (2008) 275-285.

17. D. Harvey, Modern Analytical Chemistry, $1^{\text {st }}$ ed., McGraw-Hill Book Co, Singapore, 2000, pp. 38-44.

18. International Conference on Harmonisation of Technical Requirements for Registration of Pharmaceuticals for Human Use, ICH Harmonised Tripartite Guidelines, Validation of Analytical Procedures: Text and Methodology Q2 (R1), Current Step 4 version, Nov. 1996, Geneva, Nov. 2005.

$S A \check{Z} E T A K$

\section{Razvoj i validacija spektrofotometrijskih metoda za određivanje ceftazidima u farmaceutskim doziranim pripravcima}

BASAVARAJ HIREMATH i BENNIKALLU HIRE MATHADA MRUTHYUNJAYASWAMY

Razvijene su dvije spektrofotometrijske metode za određivanje ceftazidima (CFZM), čistog ili u farmaceutskim pripravcima. Prva metoda se temelji na reakciji 3-metilbenzotiazolin-2-on hidrazona (MBTH) sa ceftazidimom u prisutnosti željezovog(III) klorida $u$ kiselom mediju. Nastaje plavi kompleks s maksimumom apsorpcije pri $\lambda_{\max } 628 \mathrm{~nm}$. Druga metoda se temelji na reakciji između diazotiranog lijeka i $N$-(1-naftil)etilendiamin dihidroklorida (NEDA), pri čemu nastaje ljubičasti produkt s $\lambda_{\max }$ pri $567 \mathrm{~nm}$. Reakcijski uvjeti su optimirani da se dobije maksimalni intenzitet boje. Apsorbancija raste linearno s porašću koncentracije CFZM; sustavi slijede Beerov zakon u koncentracijskom području 2-10 za MBTH metodu i $1050 \mu \mathrm{g} \mathrm{mL}{ }^{-1}$ za NEDA metodu. LOD i $L O Q$ te vrijednosti korelacijskog koeficijenta su 0,15, 0,79 i 0,50, 2,61. Uobičajene pomoćne tvari ne smetaju određivanju ceftazidima. Predložene metode su jednostavne, osjetljive, točne i pogodne za primjenu u kontroli kvalitete.

Ključne riječi: ceftazidim, diazotacija, spektrofotometrija, farmaceutski pripravak

Department of Chemistry, Gulbarga University, Gulbarga-585 106, India 